\title{
Poaching and its Potential to Impact Wildlife Tourism: An Assessment of Poaching Trends in the Mole National Park in Ghana
}

\author{
By Richard Obour * \\ Richard Asare \\ Paul Ankomah \\ Trent Larson ${ }^{+}$
}

Poaching poses serious threats to conservation and wildife tourism development efforts in Sub-Saharan Africa, including Ghana. This paper was based on the contemporary levels of poaching in the Mole National Park (MNP), a major destination for experiencing wildlife in their natural settings in Ghana. The study describes poaching trends in MNP; assesses the influence of anti-poaching measures and the effect of poaching on large mammal numbers in the park. Snowball sampling method was used to conduct interviews and field data were collected by observations and the use of GPS during patrols with law enforcement units. The study results showed no significant drop in poaching trends. However, the number of poachers who were arrested and those who escaped arrest increased during the same time period. The study revealed that aside from the carnivore species which showed a dip in numbers, most animals tallied showed an increase despite the high rate of poaching.

Keywords: national parks, large mammals, snowball sampling, elephant, wildlife, conservation

\section{Introduction}

Sub-Saharan African countries are searching for new models to stimulate economic growth. Tourism is viewed by many of these countries as a favorable alternative for development. One of the attractive strategies countries are using to enhance their tourism is the creation of national parks to preserve wildlife and to attract tourists in the form of wildlife tourism. Ghana like other SubSaharan African countries has established several protected areas to preserve wildlife and encourage tourism. However, these efforts at preserving wildlife through the establishment of protected areas are under threat by poaching of wildlife, the main attraction to these areas. The authorities of MNP, one of the established wildlife tourism destinations in Ghana have enacted poaching measures to curtail illegal poaching. The objectives of this paper are to uncover poaching trends in MNP and to identify strategies implemented to curtail

\footnotetext{
* Faculty, University of Energy and Natural Resources, Ghana.

${ }^{\dagger}$ Park Ranger, Law Enforcement Unit, Mole National Park, Ghana.

* Professor, North Carolina A\&T State University, USA.

${ }^{+}$Associate Professor, North Carolina A\&T State University, USA.
} 
poaching and to assess the effectiveness of these measures in alleviating this threat in MNP.

Poaching has become one of the ever growing problems facing wildlife conservation and a potential threat to wildlife tourism development efforts. This paper focuses on poaching trends in MNP in Ghana and is divided into three sections. The first section provides an overview of the challenges/ problems of wildlife conservation in Sub-Saharan Africa. Next, the section reviews the literature on poaching; specifically it provides an overview of poaching from a global perspective and examines poaching in the context of Sub-Saharan Africa (SSA). The section also addresses theories that have been expounded to explain poaching and its underpinning motivations. The second section provides an overview of poaching in Ghana and also discusses the data collection, analyses and findings of the study. The third and final section, the conclusion, summarizes the findings and provides some suggestions or strategies to curtail or minimize this environmental scourge to lessen the threat posed by poaching to wildlife tourism in the MNP.

\section{Overview of Wildlife Conservation in Sub-Saharan Africa}

Before delving into the literature review on poaching, the paper provides an overview of some of the challenges/problems constraining wildlife conservation in Sub-Saharan Africa. One of the challenges/problems identified by Pearce (2010) deals with the genesis of the concept of national parks. According to this view, the conservation of wildlife in Sub-Saharan Africa in the form of enclaves excluding humans was based on a model or template of the open space national park concept which had its origins in the United States. The author points out that when the sub-region's parks like the Serengeti and Maasai Mara, Tsavo and Selous, Kafue, Okavango, Kruger, etc. were established, these areas had human societies and their domestic animals interacting with wildlife prior to the arrival of the white colonialists. These new colonial settlers brought with them livestock from Asia that carried the virus rinderpest which not only decimated the native livestock but also wiped out the native populations in these areas. Consequently, these areas appeared to the subsequent founders of the sub-region's national parks as primeval and pristine areas worthy of cordoning off and protecting from local African populations. In other words, it is argued that wholesale transfer of a foreign concept without any modifications or considerations of local conditions, created the subsequent conflict between humans and wildlife now rife in the sub-region.

Rapid population growth and poverty have also resulted in several problems for wildlife conservation in the sub-region. The World Population Data Sheet projects that Africa's population will double to about 2.4 billion by 2050 (Population Reference Bureau, 2013). This rapid population growth has several implications for wildlife conservation. First, there is a growing pressure on very limited arable lands for subsistence farming which pushes farmers further into marginal environments and wildlife habitats. Furthermore, the 
growth in the population has also meant migration from rural to urban areas in search for non-existent jobs. These new urban populations have created a thriving market for bushmeat with its associated consequence of poaching of wildlife.

Thirdly, the integration of the rural populations into the global economy has created opportunities for the sale of wildlife parts including ivory to growing global economic juggernauts such as China. This avenue to generate foreign currency is viewed as an opportunity to supplement unreliable and meager incomes from subsistence farming.

Another problem is the lack of legal backing and enforcement of agreed upon issues between local communities and government/park authorities. Many of these parks were established without any legal agreement with resident communities (Lindsey, et al., 2014). In the few cases where legal agreements were entered into to provide resident communities access to resources and economic benefits from the community-based conservation approach, the terms of these agreements were never fulfilled, creating animosity and suspicion of displaced resident rural communities towards wildlife conservation efforts (Muhumuza and Balkwill, 2013). Like other SubSaharan African countries, similar challenges/problems to wildlife conservation may be identified in Ghana. One of the problems, poaching, is the focus of this paper. The next section reviews the literature on poaching globally and discusses the issue in the context of Sub-Saharan Africa.

\section{Literature Review on Poaching}

Despite the combined efforts of governments and conservation NGOs to protect indigenous wildlife species globally, some animal populations continue to decline. These declines are attributable to a myriad of factors including habitat destruction, a byproduct of mining, logging and other human activities that remove natural resources, introduction of non-native species to habitats, fluctuations in climate (drought, floods, etc.), and poaching (Musyoki et al., 2012). Of these factors, poaching is becoming more prevalent and destructive (Gao and Clark, 2014). Poaching is the illegal killing of wildlife against established laws (local, federal or international) and includes any unlicensed taking of animals, animals taken out of season, in excess of bag limits, by banned weapons or during trespassing (Lin, 2014). Poaching may also be viewed as any unauthorized killing or capturing of wildlife, especially when this involves any species designated as endangered, rare or protected (Blevins and Edwards, 2009). In fact, poachers plunder a variety of wildlife including birds, reptiles, and big game (Wilson-Wade, 2010).Also important in distinguishing poaching offenses from legal hunting is the manner in which animals are slain or trapped. Examples of banned methods include "hunting out of season, spotlighting while hunting at night, trespassing and using illegal weapons (Blevins and Edwards, 2009, p.560). 
Globally, the problem of wildlife poaching has reached epic proportions with estimates ranging from $\$ 5$ billion to $\$ 20$ billion annually (Lawson and Vines, 2014). In North America, illegal hunting activities severely impact populations of grizzly bears, bighorn sheep, moose, and walruses as poachers sell wildlife products -e.g. the paws, bladders and meat of bears; walrus tusks as ivory; and animal antlers and pelts (Musgrave, Parker, and Wolok, 1993). In Asia, poaching has reached critical levels for animals such as tigers (Global Tiger Initiative Secretariat, 2012), pangolins (Duckworth et al., 2008; Wu et al., 2004), and the Asiatic black bear (Garshelis and Steinmetz, 2008). A particular wildlife item featuring prominently in the illegal activity of poaching and its associated global trade is elephant ivory. The ivory from one elephant (about $10 \mathrm{~kg}$ ) has a market value of roughly $\$ 30,000$ (Vira and Ewing, 2014). Despite sanctions on the illegal trade of ivory, the current number of transactions globally has more than doubled since 2007 and tripled the previous high reached in 1998; in Beijing for instance, ivory sells for up to $\$ 2,205$ per kilogram and rhino horn for $\$ 66,139$ per kilogram, a higher value than either gold or platinum sold on the Chinese black market (Lawson and Vines, 2014).

The problem of poaching and its impact on wildlife appears to be more exacerbated in Sub-Saharan Africa. Poachers and non-state actors (e.g. rebel movements such as The Lord's Resistance Army) have introduced a more lethal and destructive dimension to the plunder of wildlife. The brutal actors target elephants and rhinos with more sophisticated weaponry and technology to fund domestic insurgencies and never-ending civil wars. Incidents of poaching committed by terrorist groups occur in several "hotspots" in the subregion. In Cameroon for instance, during a single week, at least 86 elephants (among them 33 pregnant females and their calves) were slaughtered and over the first three months of 2012 more than 100 elephants were slain at BoubaNdjida National Park; the Janjaweed militia of Western Sudan aided by neighboring Chadians were the alleged perpetrators (Quarterman, 2013). An undercover investigation sponsored by the Elephant Action League revealed that Al Shabaab, an affiliate of Al-Qaeda and the group known for the infamous attack on civilians at a mall in Nairobi, Kenya, generates approximately $40 \%$ (between $\$ 200,000$ and $\$ 600,000$ per month) of its annual operating funds from the sale of illegal ivory (Kalron and Crosta, 2012). Allegations of terrorist involvement in wildlife poaching include not only AlShabaab in Kenya, but also the Boko Haram in Nigeria and the Lord Resistance Army (in the Central African Republic and the Democratic Republic of Congo) among others (Poaching and Terrorism, 2015). This unsanctioned slaughter of wildlife is to fuel the demands of middle class customers from areas such as Southeast Asia that value ivory products and rhino horn as status symbols and for ingredient remedies in traditional medicine (Lawson and Vines, 2014).

African elephant (Loxodontaafricana) populations dropped by $64 \%$ between 1979 and 1987 from an estimated 1.3 million to 472,000 (Scriber,2014). This is largely attributed to ivory poaching. The poaching 
threat to elephants has evolved from a handful of poachers downing elephants in the mid-1950s with poison arrows (Shauer, 2015) to mass slayings of elephants by militarized gangs equipped with night vision goggles, rocket launchers and helicopters (Walker, 2013). To avoid being discovered by law enforcement, some poachers are abandoning noisy firearms and resorting to tactics such as poisoning water holes, often resulting in the death of entire herds of elephants as well as other animals (Eller, 2014; Thornycroft and Laing, 2013). For instance in neighboring Gabon's Minkebe National Park, the forest elephant population has plunged from an estimated 21,000 to 11,100, nearly a 50 percent reduction in the last 10 years - a result of poaching operations supported by the infrastructure of mining camps in the area (Agence Nationale des Parcs Nationaux, 2013). In Zimbabwe, poachers dispensed cyanide into water holes and on salt licks resulting in the death of more than 300 elephants and subsequently other animals (e.g. lions, hyenas) that came to dine on the elephant carcasses there (Thornycroft and Laing, 2013). In Mozambique, South Africa and Zimbabwe, poachers tend to refrain from using firearms as killing tactics, preferring more silent methods (e.g. tranquilizers, crossbows and poisons) to prevent game wardens from discovering their presence (Miliken, Emslie, and Talukder, 2009). In 2013 in Kenya, 117 elephants were slaughtered to feed the demand of consumers, their ivory and other parts going for astronomical prices on the black markets of Asia (Messenger, 2013).

These poachers have extended the slaughter of elephants to other species and have begun to harvest rhinos for their teeth and horns. In Kenya, 21 rhinos were killed to satisfy the demand for rhino teeth in Southeast Asia (Messenger, 2013). In terms of the most profitable illegal items traded in the world, wildlife trafficking ranks among the top five along with drugs, human trafficking, counterfeiting, and weapons (Council on Foreign Relations, 2013). With the evergrowing and seemingly limitless global demand for rhino and elephant ivory, poaching of wildlife in Sub-Saharan Africa has assumed a very deadly and dangerous dimension.

During 2013 in South Africa, more than 1000 rhinos were poached and 606 of these killings occurred in Kruger National Park (Department of Environmental Affairs, Republic of South Africa, 2014). Dwindling elephant herds and rhinos is not the only problem faced by wildlife. Declines in the population density of buffalo, eland, impala, reedbuck, topi, warthog, and waterbuck were in part due to poaching activities in the Katavi National Park and Rukwa Game Reserve in Western Tanzania (Caro et al., 2013; Martin and Caro, 2013). To minimize the appeal of illegal hunting, the Kenyan Parliament enacted a law that substantially raised the fines levied against arrested poachers to $\$ 120,000$ coupled with 15 years incarceration. Before the enactment of the law, punishment meted out to offenders amounted to no more than a slap on the wrist. As a result of poaching, Kenya's elephants declined from 160,000 in 1960 s to 16,000 in 1989 and currently there are only about 3,850 elephants and 1,025 rhinos left in the country (Messenger, 2013). The population of the sable antelope, located in Kenya, has fallen to an estimated 70 animals over the last 
three decades (Musyoki et al., 2012). The costs of poaching on wildlife are many and varied and often include the inhibition of population growth, collapse of geographic ranges and ultimately extinction of species (Woodroffe, Thirgood, and Rabinowitz, 2005) and consequently, wildlife tourism development efforts. The next section focuses on theoretical frameworks advanced to rationalize poaching behaviors.

\section{Theoretical Framework Explaining Poaching Behavior}

Three primary theoretical approaches have been advanced to explain poaching behavior. The first is differential association theory (Sutherland, 1974) which proposes that people make decisions about their behavior based on the influences of individuals (family, friends, peers) in their environment. For instance, people living in a community or with a family member or friends that engage in poaching activities are more likely to also participate in these same activities. Through the interactions with others, individuals learn poaching skills/techniques and develop a favorable mindset (motives, attitudes, justifications) towards poaching wildlife.

Another, closely-related approach is the neutralization theory developed by Sykes and Matza (1957). This theory provides rationalizations or neutralizations individuals might give for their poaching behavior and include the following practices: denial of responsibility, denial of injury, denial of victim, condemnation of condemners and appeal to higher authority (Sykes and Matza, 1957). Denying responsibility for killing/taking wildlife means that a poacher blames elements of the community environment (e.g. family, friends engaged in poaching activities) as the proximate cause of their illegal behavior to deflect criticism from accusers. In the case of denying injury from poaching behavior, the perpetrator seeks to minimize the seriousness of the offense by comparing it to other illegal activities more egregious in nature. Another rationalizing strategy (denial of victim) for poachers to employ would be that extenuating circumstances of the environment (indigence, deprivation, influence of terrorists, etc.) lead to their unlawful behavior. Sometimes poachers resort to attacking the character of condemners by searching for former negligent behaviors and ulterior motives the condemners might be harboring.

A third theory that forms a theoretical framework for poaching is the routine activities theory (Cohen and Felson, 1979; Vold et al., 2002). This theory is based on three key elements that influence deviant behavior: the presence of motivated offenders willing to commit an illegal act, suitable targets accessible to the offender, and the lack of capable guardians protecting the targets.

Motivations for poaching have been studied from many angles. In a study of poachers and game wardens, motivations for illegal hunting consisted of four main categories: food (sustenance and goods for members of the household/close friends), money (selling illegally taken meat to generate funds for family, business needs or extra personal income), tradition (participating in 
hunting activities as a means of preserving personal and cultural history), and exhilaration (excitement experienced by eluding capture by game wardens) (Forsyth, et al., 1998). Muth and Bowe (1998) created a typology of 10 motives for poaching behaviors. These motives include commercial gain, household consumption, recreational satisfactions, trophy poaching, thrill killing, protection of self and property, poaching expressed as a type of rebellion, poaching as a traditional right of residents, disagreement with specific regulations of hunting laws and, gamesmanship.

\section{Overview of Poaching in Ghana}

Poaching poses a growing problem for wildlife tourism development in Ghana as it pertains to other countries in the sub-region. Henk (2005) identified three types of poaching behaviors in Sub-Saharan Africa: subsistence, trophy and commercial. Subsistence poachers are those who hunt wildlife illegally as food sources. This practice includes the taking of animals including duikers and buffaloes (Henk, 2005). Subsistence poachers pose very little, if any, threat to wildlife. However, subsistence poaching is expanding to incorporate large scale killing and trading of endangered species (Lemieux and Clarke, 2009) and could eventually rival commercial poaching in very destructive ways.

The primary objective of trophy poachers is to collect the best possible animal trophies for a personal collection or in some cases to sell the heads, antlers and hides of trophy animals for profit (Blevins and Edwards, 2009; Eliason, 2013). Additionally, hunters who have an obsession with trophy animals are more likely to be involved in poaching behaviors. Trophy poachers are not a serious threat in Ghana.

The major threat to the survival of endangered wildlife species in Ghana is the threat from commercial poachersand the new breed of subsistence poachers involved in the large scale trade in endangered wildlife species. Recognizing the value of wildlife and the hunting pressures associated with it, traditional Ghanaian societies established systems to regulate and control access to wildlife resources. The first wildlife laws (Game Preservation Ordinance) were promulgated in 1901 to regulate hunting and protect certain wild animal species (Ofori-Frimpong 2004).

The network of Protected Areas (PAs) is a fair representation of all ecosystems in Ghana, namely: Guinea Savannah woodland, transition between dry forest and Guinea Savannah, dry semi-deciduous forest types, wet evergreen forest, moist evergreen forest, transition zone between moistevergreen and moist semi-deciduous forest types and coastal savannah. Wildlife Division's protection efforts are primarily concentrated in the PAs which form about $6 \%$ of the total land surface area of Ghana. This leaves $94 \%$ of the country's ecosystem at the mercy of the numerous hunters and farmers who harvest wildlife indiscriminately despite a temporary ban on hunting except the Grasscutter (Thryonomysswinderianus) from $1^{\text {st }}$ August to $1^{\text {st }}$ December each year (IUCN, 2006). 
In Ghana, Mole National Park (MNP) is the largest Wildlife Protected Area (WPA). Faunal species that serve as attractions to tourists visiting the park include some 94 mammal species, over 300 bird species, 9 amphibian species and 33 reptile species (Mole National Park, 2010). The large mammals include Elephant (Loxodontaafricana), Buffalo (Synceruscaffer), Roan antelope (Hippotragusequinus), Hartebeest (Alcelaphusbuselaphus), Waterbuck (Kobus ellipsiprymnus) and Kob (Kobus kob). Predators include Lion (Pantheraleo), Leopard (Pantherapardus), Spotted hyaena (Crocutacrocuta), Caracal (Felis caracal), Aardvark (Oryteropusafer), Genet (Genettamaculata) and Mongoose (Crossarchusobscuras). Other attractions in the park include birdwatching, camping, visitations and experiencing cultural heritage architecture and traditional livelihoods of communities in close proximity to the park.

All PAs in Ghana lack buffer zones and have become ecological islands, and wildlife conservation has not been treated as a priority by successive governments compounding their vulnerability (IUCN, 2006). Most of the communities in close proximity to MNP have become antagonistic to the concept of conservation and in the communities where the influence of the Wildlife Division's staff is nonexistent, wildlife species and numbers have declined significantly. Since wild animal numbers serve as index of the health of the land, currently MNP appears to be the healthiest amongst all the PAs in Ghana. Consequently, the park serves as field laboratory for universities in Ghana and their international partnership institutions and researchers. Currently, MNP records tourists' arrival in the range of 17,000 per annum and the number is estimated as increasing at an average rate of $10 \%$ per annum (Mole National Park, 2010).

The MNP is home to large mammal species such as the African elephant, the leopard, the buffalo, the lion, the Roan antelope, the Bushbuck, the Kob, the Hartebeest, the Giant Pangolin, etc. Many of these species are captured in the IUCN 2009 Red list as either vulnerable, endangered or threatened species. Some of these large mammals which attract most tourists are also the target of poaching for commercial purposes and dinner tables of locals. Research by Lani (2007) indicated that the main sources of bushmeat supply to Techiman market in Ghana were: Damongo, Daboya, Kabampe and Tuna, which are communities in close proximity to Mole National Park. Of an estimated number of 589 elephants recorded in 1993 only 401 were left in 2006 mainly due to poaching (Bouchè, 2006).

Poaching has the capacity to dwindle the fortunes of the MNP with regard to wildlife tourism development, one of the important elements underpinning the 2011 Ghana Forest and Wildlife Policy. Consequently, there was a need to conduct an assessment of poaching trends that could inform management decisions for conducting future anti-poaching patrols and developing wildlife policies. The information obtained can also be used as an important guide for future research. The main objectives of the study were to assess the trend of poaching in the MNP and its impact on this park. Findings will provide information on trends, spatial distribution of poaching and drivers of this illegal 
activity and eventually result in the formulation of strategies that would help curtail the menace and enhance wildlife tourism development.

\section{Methodology}

The study methodology followed a sequence of steps to achieve the objectives of the paper. First, a description of the area in which the study was conducted is presented to provide the reader with some background and geographic information of MNP. Next, the type of data collected and the rational for collecting them are outlined. Primary data were collected from park rangers and authorities and included specific anti-poaching measures enacted and strategies used to monitor these measures. Secondary data from ranger patrols, number of arrests, sentences imposed on culprits, wildlife carcasses observed and recorded during patrols were also obtained. The aforementioned data had the purpose of providing empirical evidence regarding poaching measures enacted by the MNP authorities and also helping to address the stated objectives of the study (identifying poaching trends and the effectives antipoaching measures on curtailing poaching in MNP).

For the fringe communities, mostly primary data were collected on their economic activities, their involvement in illegal poaching and rationale for such involvement. Furthermore, their views on how this illegal activity could be minimized and information on their demographic characteristics were also obtained. All these data had the cardinal purpose of helping to understand poaching trends as well as to provide insight into how successful enacted poaching measures have been in MNP. The remainder of this section describes the study area and data collection procedures.

\section{Study Area}

Mole National Park (MNP) is located in the Northern Region of Ghana and covers about $4,577 \mathrm{~km}^{2}$. It is located in a fairly undisturbed portion of the Guinea Savannah Zone and lies between latitudes $9^{\circ} 11^{\prime}$ and $10^{\circ} 10^{\prime} \mathrm{N}$, and longitudes $1^{\circ} 22^{\prime}$ and $2^{\circ} 13^{\prime} \mathrm{W}$. The dominant vegetation is open savannah woodland with grasses that can reach $3 \mathrm{~m}$ high during the rainy season, and about 742 plant species. Schmit and Adu-Nsiah (1993) have recognized four savannah vegetation types in the West Gonja District. These are the Terminalia macroptera - Loudetiopsisthoroldi-type in badly-drained and seasonally flooded plains, the Mitragynainermis - Andropogongayanus var. gayanus-type in valley bottoms along streams, the Isoberliniadoka-Loudetiopsisscaethae Hyperrheniasubplumosa-type on gentle slopes and well-drained plains and the Loudetiopsiskerstingii-Polycarpaeatenuifolia-type on iron stone plateau. There are 33 communities on the immediate fringes of the park with a total population of about 40,000 people. Most of these rural residents are poor farmers, who often resort to illegal extraction of natural resources from the 
park for their survival. The park is buffered by several farms and hunting areas (Figure 1).

Figure 1. Map of Ghana showing MNP

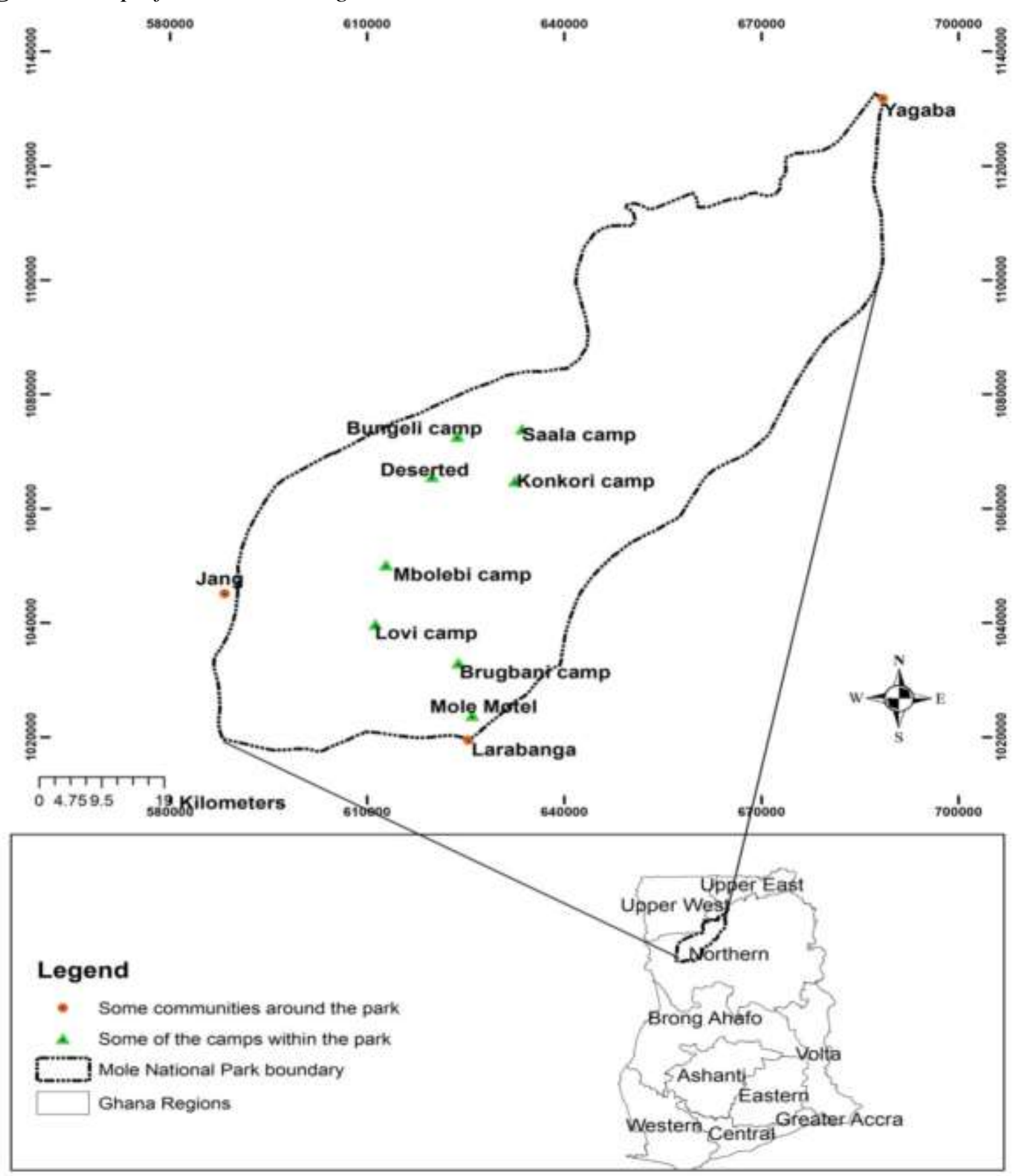

\section{Data Collection}

Primary sources of data include the data collected from wildlife staff and poachers in selected fringe communities. Interview questionnaires were used to 
obtain responses from key informants such as the wildlife guards. A total of twelve staff were interviewed; three staff from each range - Bawena, Ducie, Jang and Headquarters ranges. Six fringe communities were also selected based on the communities with high records of poacher arrests during the five year period of field patrols (2008-2012). The communities were: Holomuni, Kabampe, Ducie, Larabanga, Bawena and Grunbelle. Snowball sampling techniquewas employed in selecting poachers from the chosen communities. This nonrandom sampling method assists researchers in swiftly identifying members of obscure, difficult-to-locate populations (e.g. those engaged in sensitive or illegal behaviors) for inclusion in qualitative research (Biernacki and Waldorf, 1981;

Faugier and Sargeant, 1997; Sadler, Lee, Lim and Fullerton, 2010). The selection process begins with the identification and recruitment of an individual with the desired characteristics and then accesses the person's social network to find another respondent with similar traits to be a part of the study; the same process continues with each subsequent person until an adequate number of respondents is gathered (Sadler et al., 2010). Most of the poachers interviewed had been arrested previously in the park and their photographs taken by the park authorities. Twelve poachers were interviewed in all, two poachers from each community.

Secondary data were collected by examining past records of poaching activities over a period of five years (2008 to 2012) at the law enforcement unit of the park from field patrols using patrol forms. Patrol data forms contain information gathered daily from the field during patrols using GPS (Global Positioning System), which included the names of the patrol leader, GPS user, patrol team, hours spent in field, animals sighted and carcasses of dead animals encountered. The form also contained signs of illegal activities such as poaching camps, poachers' foot prints, gunshots heard, poachers observed and poachers arrested. Waypoints of all the observations made were taken to illustrate the exact locations of illegal activities recorded in the field and downloaded on MIST (Management Information System), a relatively simple GIS system for displaying and analyzing data that have been gathered by Wildlife Guards on patrol introduced in October 2004. MIST can also be used to direct and monitor patrols.

Observations of poaching relics in the field were made for four months spanning January to April, 2013. The time of data collection corresponded with the main poaching season during which poaching signs were rife and very visible, especially around saltlicks and water-holes.

\section{Implementation of Regular System of Extended and Local Patrols}

A regular patrolling routine which is unpredictable in nature has been established to maintain presence of patrol staff within the protected areas. While on patrol, every field staff must work for at least 6 hours per day. However, for all the protected areas in Ghana, the duration of an effective patrol day has been pegged at 8 hours. The hours a team spends in the field are 
used to calculate Effective Patrol Man-days, which constitute the measure of effort of the team.

Effective patrol man-days $=\underline{\text { Number of hours spent } \times \text { Number of patrol }}$ staff $8 \mathrm{hrs}$. (Standardized)

Distances for local patrols are determined by local needs. The policy of all parks where MIST GIS has been introduced requires that every field staff spend at least 15 days per month on patrols in the field. Officers participate frequently in field exercises to ensure that all aspects of law enforcement are receiving the deserved attention. Officer participation is the most important element of successful law enforcement.

\section{Data Analysis}

The quantitative and qualitative data collected through interviews and those from the office of the law enforcement unit were entered into a computer. Microsoft Excel software was used for the data analyses and the results are presented in the form of tables, bar and pie charts.

\section{Results}

Reported Illegal Poaching Activities in MNP and Disciplinary Measures Taken

Table 1. Reported Illegal Poaching Activities in MNP and Disciplinary Measures Taken

\begin{tabular}{|c|c|c|c|c|c|c|}
\hline Year & $\mathbf{2 0 0 8}$ & $\mathbf{2 0 0 9}$ & $\mathbf{2 0 1 0}$ & $\mathbf{2 0 1 1}$ & $\mathbf{2 0 1 2}$ & Total \\
\hline $\begin{array}{c}\text { No. of } \\
\text { patrols } \\
\text { conducted }\end{array}$ & 2635 & 3315 & 4157 & 4434 & 4125 & 18666 \\
\hline $\begin{array}{c}\text { Poachers } \\
\text { arrested }\end{array}$ & 27 & 20 & 24 & 26 & 25 & 122 \\
\hline $\begin{array}{c}\text { Poachers } \\
\text { observed }\end{array}$ & 21 & 8 & 4 & 7 & 15 & 55 \\
\hline $\begin{array}{c}\text { Firearms } \\
\text { confiscated }\end{array}$ & 9 & 10 & 14 & 13 & 17 & 63 \\
\hline $\begin{array}{c}\text { Gin traps } \\
\text { confiscated }\end{array}$ & 25 & 19 & 13 & 6 & 7 & 70 \\
\hline $\begin{array}{c}\text { Animal } \\
\text { carcasses }\end{array}$ & 37 & 6 & 21 & 17 & 20 & 101 \\
\hline $\begin{array}{c}\text { Gunshots } \\
\text { heard }\end{array}$ & 17 & 21 & 33 & 13 & 13 & 97 \\
\hline $\begin{array}{c}\text { Fines } \\
\text { (GH } \varnothing \text { ) }\end{array}$ & 6,370 & 3,640 & 3,730 & 4,500 & 10,890 & 29,130 \\
\hline $\begin{array}{c}\text { Prison } \\
\text { sentence } \\
\text { (Months) }\end{array}$ & 594 & 60 & 25 & 26 & 24 & 729 \\
\hline
\end{tabular}


The data for the analyses were generated from 18,666 anti-poaching patrols conducted in Mole National Park from January 2008 to December 2012. The highest number of patrols conducted was recorded in the year 2011 (4434 patrols) and the least number of patrols was recorded in 2008 (2635 patrols). The trend of illegal activities was high in 2008 (136) and declined to its lowest in 2011 (82) (Table 1). The overall occurrences of individual illegal activities recorded over a 5 year period under review indicated that poachers arrested was the most frequently recorded (122 occurrences) and poachers observed but escaped arrest was the least of all the observations made (55 occurrences).

The highest number of poacher arrests was recorded in 2008 (27 arrests) with a corresponding monetary fine totaling $\mathrm{GH} \phi 6370$ and 594 months of prison sentences. The least number of arrests was recorded in 2009 (20 arrests) with a corresponding fine of $\mathrm{GH} \phi 3640$ and 60 months of prison term on all offenders (Table 1).

The number of patrols increased consistently from 3,315 in 2009 to 4,434 in 2011, because 40 new staff were recruited to augment the numerical staff strength of the law enforcement unit and there was an improvement in supervision by officers who participated frequently in field exercises to ensure that all aspects of law enforcement were receiving the required attention. From the five year report, it was evident that in 2008, poaching activities were very high 24\% (122 out of 508). This was due to low staff supervision and low number of patrol staff.

The data proved that after the drastic drop of poaching activities from 136 in 2008 to 84 in 2009, poaching trends fluctuated until 2012. The decrease in poacher arrests and poaching activities was because the number of field patrols increased and became more efficient and effective. This fluctuating trend could also be attributed to among other things, inappropriate field patrols made by some staff along tracks and roads which were not used by poachers and so such patrols missed poachers and their activities. This might also be due to low levels of evening/night patrols as captured in the records from field patrols, because research has shown that most of the poaching in MNP occurred at night. The result confirmed the Holmern, et al. (2007) finding that not every part of the park could be patrolled and there was the possibility that illegal activities occurring in certain parts of the park could be high.

From Table 1, it is evident the initial high rate of poaching necessitated effective law enforcement such as arrests, relatively high fines and long prison sentences, which lowered the rate of poaching in 2009. However in 2012 the trend was reversed; punishments given to offenders for poaching declined over the years and perhaps an increasing demand for meat stimulated poaching to revert back to appreciable levels. The low priority for wildlife conservation, low fines and prison sentences appear to sustain poaching in MNP. This finding is consistent with a similar study conclusion by Niraj (2009) in India. The study reported that field officials (37\%), policy makers $(45 \%)$, NGOs $(60 \%)$ and scientists $(73 \%)$ stated that there was low priority for wildlife conservation in that country. 


\section{Poaching Profile of Fringe Communities to MNP}

The results presented in Figure 2 showed that Holomuni and Kabampe recorded the highest number of poacher arrests from 2008 to 2012 with 11 arrests each. Communities where the least numbers of poachers were arrested include, Nyole, Chasia, Kpulumbo, Tantale and Grupe recording only one arrest each from 2008 to 2012.

Figure 2. Poachers Community Profile and Number of Arrests from 2008 to 2012

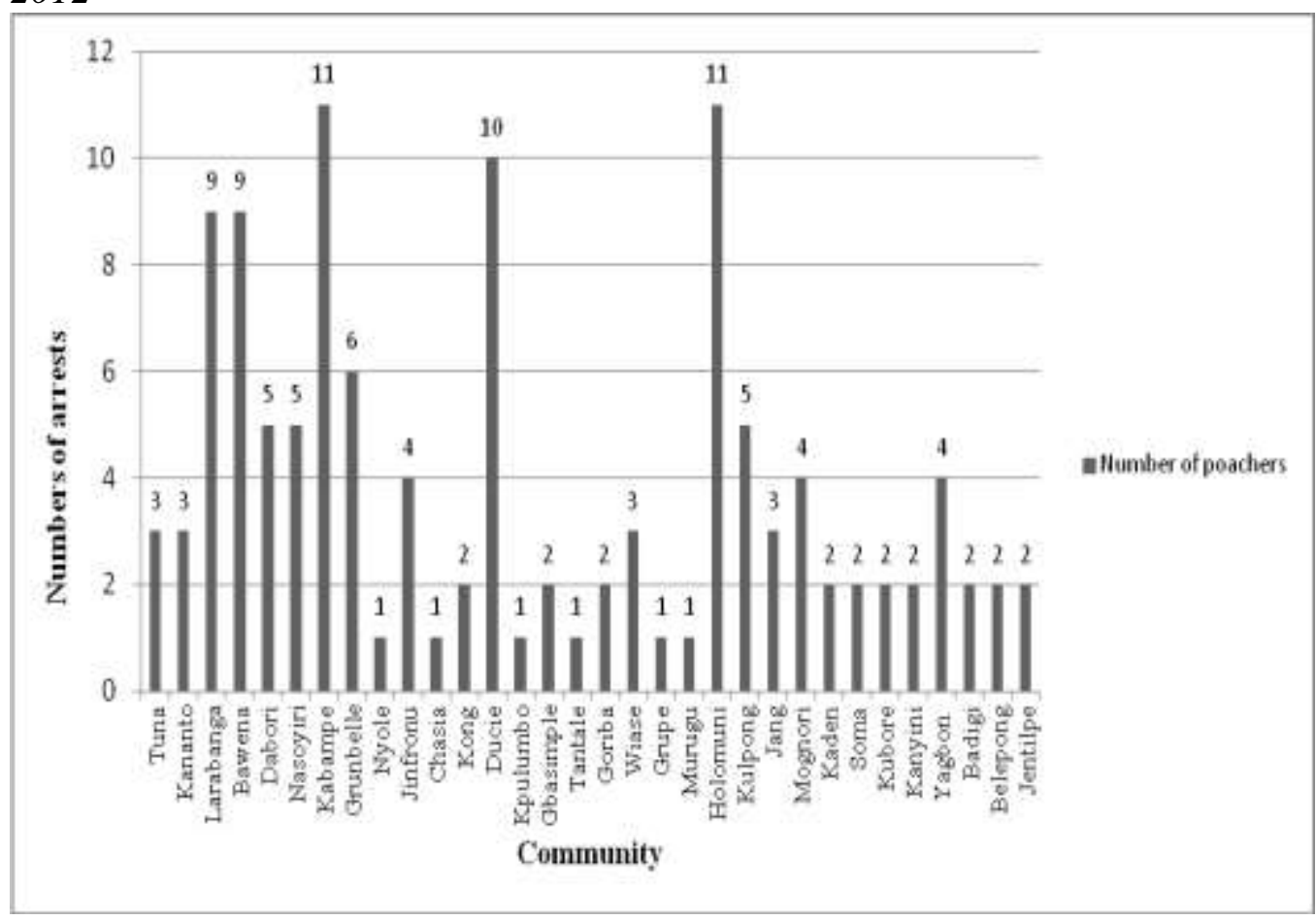

Poaching puts pressure on staff efforts and strength, especially, where the numerical staff strength is inconsistent with the size of the park to adequately counteract the activities of poachers. However, anti-poaching activities in Mole National Park (MNP) have impacted positively on the general numbers of the fauna species, especially the large. As more firearms were confiscated (i.e. 9, 10, 14, 13 in 2008, 2009, 2010, 2011, and 2012 respectively) so did animal numbers increase over the period. More poachers lost the capacity to poach because they had been deprived of their weapons of destruction through arrests. The more anti-poaching patrols conducted during the period under review, the higher the number of poacher arrests, which also resulted in a diminished number of illegal activities.

Punishments meted to offenders for poaching in 2008 were deterrent enough. However, the low fines levied against the poachers in 2009 and thereafter continue to make anti- poaching patrol duties more difficult in the face of mounting pressures by poachers everywhere in the park, unless drastic 
measures are put back in place to review and revise the fines and the prison sentences upward.

Figure 3. Age of Groups of People Involved in Poaching Activities

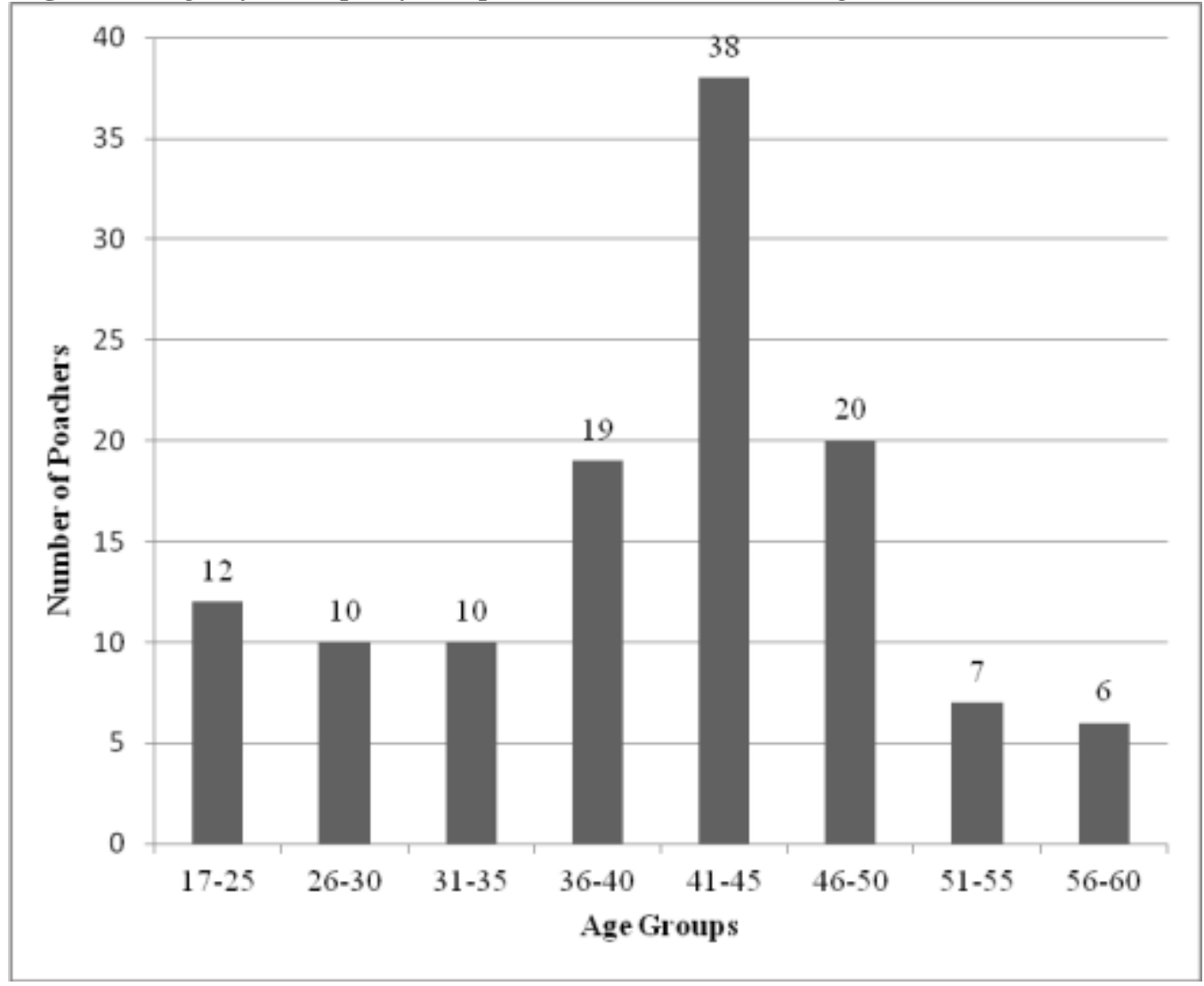

From Figure 3, the age range of poachers arrested was between 17 and 60 years with an average age of 38.5 years. The age groups with highest number of poachers were between 41 and 45 years from 2008 to 2012. It was therefore evident that people who were actively involved in poaching fell within the age brackets that had the ability to walk further into animal concentration areas to engage in poaching. These people were very active and escaped arrest most of the time. In most cases people below the age of 30 years only served as porters who brought animal carcasses home and were inexperienced in the activity of poaching.

Rate of Large Mammal Encounters in MNP from 2008 to 2012

Kob recorded the highest average number of large mammals $(19,580)$ representing $41.65 \%$, with the lion having the least recorded average number of large mammals (2) representing 0.004\% sighted in MNP from 2008 to 2012. This observation is in line with the findings of Henschel et al. (2010). According to the researchers, only $11 \%$ of respondents interviewed reported to have seen a lion within the last five years in Mole National Park, though 48\% 
had expressed familiarity with lions. These respondents suggested that the species had declined or no longer existed in the area. Nearly three-quarters (73\%) of respondents indicated that lions were used for traditional purposes (such as ceremonial skins, food and medicine).

There has been a significant decline in the lion population of MNP over the last 40 years. This decline is apparent across multiple lines of evidence: a marked decrease in sightings by patrol staff, a lack of camera trap detections or other verifiable evidence despite extensive field work and an increasing sense of scarcity conveyed by local village residents. A considerable patrol effort was expended in recent years (e.g., approximately 2700 patrols from 2005 to 2008). However, indices for many other species did not show a similar decline.

A good number of kobswere concentrated in the headquarters beat of the park, close to the dams (Dam I and II), key dry-season water sources and other water holes within the park's headquarters beat. This finding is in line with Deutsch's (1994) assertion that the habitat of kobsis often close to permanent sources of water; the habitat also includes damp savannah, floodplains, and the margins of adjacent woodlands (DuVal, 2000). In terms of economic benefits to humans, kobs attract people who hunt for sport and these animals also serve as a substantial part of the diet of local people (DuVal, 2000). In a similar study on bushmeat in Cameroon, respondents ranked kob as the third most preferred bushmeat behind North African porcupine and guineafowl (Njiforti, 1996). According to poachers interviewed for the present study, kob is preferred to other antelopes. However, night and day patrols were carried out religiously within the concentration areas of kobs and therefore access to them is a bit more difficult than other animals of the park. Although there was an increase in the animal numbers, this was not true for carnivores whose populations were dwindling at an alarming rate.

\section{Rate of Large Mammal Poaching in MNP from 2008 to 2012}

It was evident from the data that hartebeest and bushbuck (12 each) were mostly poached within the period under consideration. The least poached large mammals were buffalo and roan antelope (1 each). Apart from kob $(19,581)$, the next animal with highest average population is hartebeest $(7,855)$ (Figure 4). Hartebeest and bushbuck meats appear to be relatively high in preference and demand compared to other meats. However, according to poachers interviewed, kob and grasscutter meat commanded the highest price than any other bushmeats along the commodity chain of hunter to retail vendor.

Hartebeests are not water dependent and do not congregate at a particular area like kobs, but are scattered throughout the park and are readily available to be poached. Similarly, Bushbucks (1284) are scattered in the park and are poached to compensate for kobs which are not easily accessible. Buffalo and roan antelope poaching has declined, but that could be due to a population decline, leading to poaching of other comparable wild animals such as hartebeest to replace buffalo and roan antelope. 
Figure 4. Large Mammals Poached in MNP from 2008 to 2012

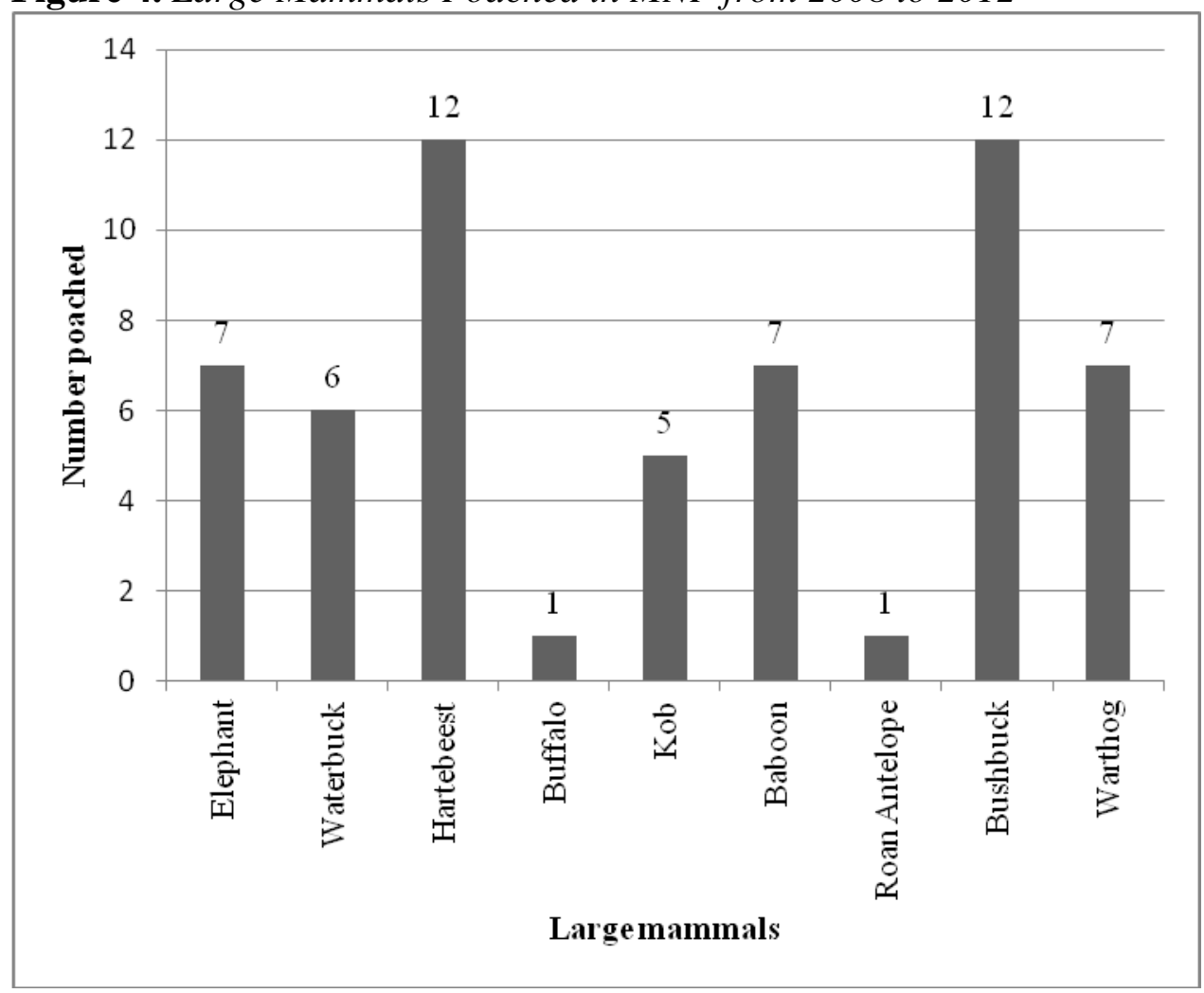

\section{Discussion}

The results of the study showed that most of the hunters interviewed engage in poaching for monetary reasons (58\%), $17 \%$ poached for food and $25 \%$ as a means of employment. Ten of the poachers interviewed were commercial hunters (Figure 5). A study in the Serengeti National

Park in Tanzania suggested similar results, $74.5 \%$ of people arrested for engaging in illegal hunting in the park did so to generate cash income and only 24.7\% maintained that they hunted for food (Loibookiet al., 2002). People poached especially during the dry season when they were not engaged in any active farm activities. A poacher who was interviewed claimed that poaching was the easiest way to make money unlike farming that has long gestation periods.

During the dry season there was tremendous under employment in communities around the Mole National Park, as farm work was exhausted during the period. This was quite evident during the study as in almost all communities the men were found resting under trees as women went about their daily chores (Danso, et al., 1994). Farm activity and labor requirements peaked around May and June, whilst in December, January and February there was practically no farm work. Incidentally, this period was also the open season for hunting and the time when animals were easily spotted. Dansoet al. (1994) suggested the introduction of dry season activities that would occupy 
the people and a change in the open season for hunting to coincide with rainy season, when the people were preoccupied with farm work and the animals are not easily spotted, to effectively reduce hunting pressure in the area.

Figure 5. Reasons for Poaching Behavior

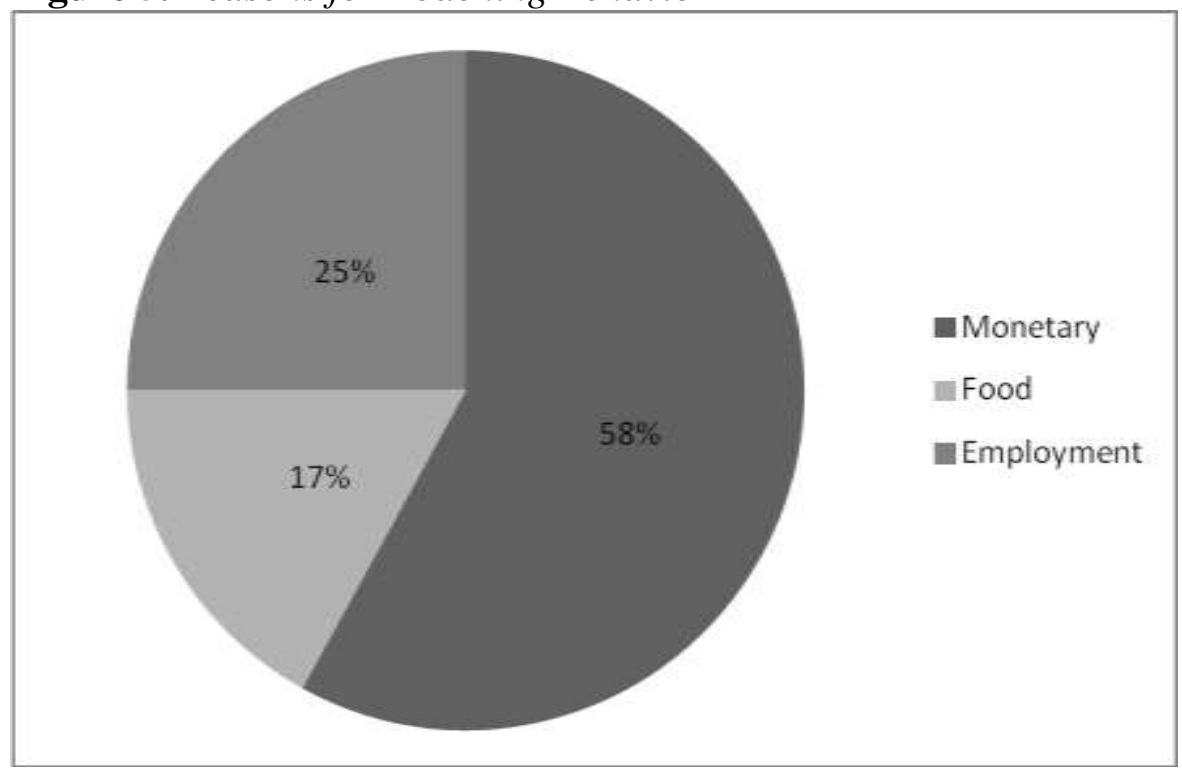

Easy cash income generated by hunting, coupled with higher per capita income relative to other alternative sources of activities and the high proportion of bushmeat as an important part of animal protein component of an average individual's diet were the major contributing factors sustaining illegal hunting (Hladiket al., 1993). In Eastern and Southern Africa, 39\% of household income is generated by the bushmeat trade (Barnett, 2000). These, along with other factors, may have deleterious genetic impact on the affected wildlife species. The unintended consequences of poaching might not be immediately obvious due to the fact that extinction of the species may occur several decades after the incidences of poaching (Kenney et al., 1995). Based on observations and responses of informants, weak law enforcement and lack of reliable means of employment to make a living were found to be critical causal factors in the poaching of large mammals. The most common weapons used for hunting were shotguns. However, when animals such as elephants and other large animals were involved, AK-47 assault rifles appeared to be weapons of choice. Rarely, gin traps may be used.

Accurate data on poaching trends is important for planning and for future management decisions. The study showed no appreciable drop in poaching trends but rather the illegal activity fluctuated as the number of poachers arrested. It declined when the number of those arrested and given long prison sentences increased but spiked when the number of arrests and associated prison sentences fell. However, there were instances during the period between 2008 and 2012 when the number of arrests made increased but there was no appreciable decline in poaching. Some of the reasons adduced for increase in 
poaching during periods of increase park patrols included possible leakage of information by some wildlife guards to the fringe communities and low levels of evening/night patrols.

These assertions were based on the fact that much of the poaching in MNP occurred at night. Hartebeest and the bushbuck were the most highly coveted and poached and the buffalo and the roan antelope the least poached wildlife. The period of record low fines and prison sentences also coincided with increased poaching. The study revealed that most animal numbers were increasing despite high rate of poaching. This anomalous finding suggested a need to frequently update the data on poaching trends in MNP to provide an accurate picture on poaching levels in the park and identify appropriate remedial measures to address the problem.

Anti-poaching activities in Mole National Park (MNP) have impacted positively on the general numbers of the fauna species, especially the large mammals. The arrests and confiscation of weapons had lessened the levels of poaching in the park resulting in reduced illegal activities and an increase in large mammal numbers. However, poaching exerts a lot of pressure on patrol staff forcing them to conduct more patrols in order to cover large areas on foot than they used to do, impacting negatively on their health. It was evident from the study that the numbers of most animal species had shot up, notwithstanding the relatively high numbers of mammals poached within the period. However, carnivore species which were nocturnal animals, decreased in numbers over the same period due to poaching particularly at night when poachers were most active. There is a reality that bushmeat constitutes a legitimate and crucial part of the economy and diet for rural dwellers. This reality conflicts with the ultimate goal of wildlife conservation which is sustainable use. Since demand for bushmeat was high, there was great potential for the illegal trade in large wild animals to increase as other bushmeats such as grasscutter and other wild animals become scarcer due to over exploitation propelled by uncontrolled human population growth and lack of economic alternatives to sustain this population.

\section{Conclusion}

The research focused on causes and impacts of poaching in Mole National Park; it was found that low fines, ineffective law enforcement and poor patrol staff supervision were the major causes of poaching within the park. To address the poaching problem to enhance and sustain wildlife tourism development, the paper suggests that efforts should be made at the national level to support wildlife conservation policies (socially, politically, and economically). The paper recommends the following policy actions and strategies specifically, to help reduce poaching in the Mole National Park. They are: 
1. Existing legislation in Ghana regarding Protected Areas (PAs) should be reviewed and revised to remove ambiguities concerning the illegal killing of animals, especially large mammals. The most effective law enforcement action to achieve long-term change in poaching would appear to involve increasing the incarceration penalties for poaching, and also equipping and training law enforcement officers more effectively.

2. Paying appropriate compensation to hardworking patrol staff, especially those who put their lives on the line to effecting arrests and jailing of poaching offenders. The staff should also be paid in a timely fashion to incentivize, build morale and provide encouragement to them to carry out their responsibilities.

3. Areas of high animal concentrations should be mapped out by the MIST application and given special attention, while simultaneously improving law enforcement monitoring in those areas.

4. Another strategy will involve the Savannah Accelerated Development Authority (SADA) widening its original scope of responsibilities. SADA was created with the objective of reversing the impact of climate change in the savannah ecological zone in Northern Ghana. Specifically, SADA has the responsibility of promoting sustainable development to minimize ecological destruction. Therefore, the scope of SADA could be expanded to incorporate the communities fringing MNP by providing alternative livelihoods in the form of wildlife tourism (ecotourism), agriculture, community-based non-timber forest product trade devised under sustainable management regimes, and creating small businesses such as grasscutter farming and guinea fowl rearing opportunities.

5. There is the need to lessen the burden on patrol staff by increasing their numbers to enable them undertake more effective and efficient patrols and making night patrols a priority. Only about 100 patrol staffs were responsible for patrolling the entire Mole National Park which covers an area of $4,577 \mathrm{~km}^{2}$ every month.

6. Additionally, the authorities of the MNP could sponsor the education of some of the youth from the fringe communities to enhance their employability within MNP as park rangers, nature interpreters, ecolodge staff and managers, etc.

\section{Acknowledgement}

We acknowledge with thanks the Wildlife Division of the Forestry Commission and the management and staff of MNP for permission and technical assistance to undertake this study in the Mole National Park. 


\section{References}

Agence Nationale des Parcs Nationaux. 2013. Wildlife and Poaching Assessment in Northeast Gabon: Preliminary Results. Online at: http://awsassets.panda.org/ downloads/preliminary_results_of_minkebe_pilot_study.pdf. (downloaded on 12 December 2015).

Barnett, R. 2000. Food for Thought: The Utilization of Wild Meat in Eastern and Southern Africa. TRAFFIC/WWF/IUCN Nairobi, Kenya.

Biernacki, P., Waldorf, D. 1981. Snowball sampling: Problems and techniques of chain referral sampling. Socio. Meth. Res., 10, 141-163.

Blevins, K., Edwards, T. (2009. Wildlife crime. In $21^{\text {st }}$ Century Criminology: A Reference Handbook, J. Miller, Ed. Sage, Thousand Oaks, CA, 557-564.

Bouchè, P., (2006). Northern Ghana Wildlife Survey, IUCN, NSBCP.

Caro, T., Elisa, M., Gara, J., Kadomo, D., Martin, A., Mushi, D., Timbaka, C. 2013. Integrating research with management: The case of Katavi National Park, Tanzania. African Zoology, 48, 1-12.

Cohen, L., Felson, M. 1979. Social change and crime rate trends: a routine activity approach. American Sociological Review, 44, 588-608.

Council on Foreign Relations. 2013. Tracking the traffickers: President Obama against poaching. Online at: http://blogs.cfn.org/campbell.2013/07/15/tracking-the-traffi ckers-president-obama-gainst-poaching. (downloaded on 15 October 2015).

Danso, E., Agyare, A., Sam, M. 1994. The Socio-economic perspective of the Mole National Park. Forest Resource Management Programme, DGW/IUCN Project 9786, Accra, Ghana

Department of Environmental Affairs, Republic of South Africa. 2014. Update on Rhino Poaching Statistics (17 January 2014 update). Online at: https://www. environment.gov.za/mediarelease/rhinopoaching_statistics_17jan2014. (downloaded on 10 November 2015).

Deutsch, J. 1994. Lekking by default: female habitat preferences and male strategies in Ungandakob. Journal of Animal Ecology, 63, 101-115.

Duckworth, J., Steinmitz, R., Pattanavibool, A., Zaw, T., Tuoc, D., Newton, P. 2008. Manis pentadactyla. IUCNRed List of Threatened Species. IUCN 2010. Version 2010.4. Online at http://www.iucnredlist.org. (downloaded on 9 September 2015).

Duval, E. 2000. Kobus kob (On-line), Animal Diversity Web. Online at: http:// animal diversity.org/accounts/Kobus.kob. (downloaded on 3 June 2016).

Eliason, S. 2013. Policing poachers in the United States: A qualitative analysis of game wardens and profiling. International Journal of Criminal Justice Sciences, $8(2), 235-247$.

Eller, J. 2014. Amid Security Concerns, Poaching Moves up International Agenda. Online at: http://www.theglobalobservatory.org/2014/01/security-concerns-arou nd-ivory-poaching-move-it-up-international-agenda/. (downloaded on 5 October 2015).

Faugier, J., Sargeant, M. 1997. Sampling hard to reach populations. Journal of Advanced Nursing, 26, 790-797.

Forsyth, C., Gramling, R., and Wooddell, G. 1998. The game of poaching: Folk crimes in southwest Louisiana. Society and Natural Resources, 11, 25-38.

Garshelis,D., and Steinmetz, R. 2008.Ursusthibetanus. In: The IUCN Red List of Threatened Species 2008. Version 3.1 
Gao, Y., and Clark, S. 2014.Elephant ivory trade in China: Trends and drivers. Biological Conservation, 180, 23-30.

Global Tiger Initiative Secretariat. 2012.Global Tiger Recovery Program Implementation Report 2012. The World Bank, Washington, D.C.

Henk, D. 2005. The Botswana defence force and the war against poachers in Southern Africa. Small Wars and Insurgencies, 16(2), 170-191.

Henschel, P., Azani, D., Burton, C., Malanda, G., Saidu, Y., Sam, M., and Hunter, L. 2010. Lion status updates from five range countries in West and Central Africa. CATNews, 52, 34-39.

Hladik, C., Hladik, A., Linares O., Pagezy H., Semple, A, Hadley M (1993) Tropical forests, people and food: Biocultural interactions and applications to development. UNESCO, Paris.

Holmern, T., Muya, J., and Røskaft, E.2007. Local law enforcement and illegal bushmeathunting outside the Serengeti National Park, Tanzania. Environmental Conservation, 34, 55-63.

IUCN.2006. Parks and Reserves of Ghana (Management Effectiveness Assessment of PAs).

IUCN. 2009. IUCN Red List of Threatened Species. Online at: http://www.redlist.org. (downloaded on 30 September 2015).

Kalron, N., and Crosta, A. 2012. Africa's white gold of jihad: al-Shabaab and conflict ivory. Online at: http://www.elephantleague.org/project/africas-white-gold-of-ji had-al-shabaab-and-conflict-ivory. (downloaded on 15 December 2015).

Kenney, J., James, L., Smith, D., Starfield, A., and McDougal, C. 1995. The long term effects of tiger poaching on population viability. Conservation Biology, 9, 11271133.

Lani, P. 2007.Bushmeat trade in Techiman Municipality. (Unpublished dissertation) Kwame Nkrumah University of Science and Technology, Kumasi, Ghana.

Lawson, K. and Vines, A. 2014.Global Impacts of the Illegal Wildlife Trade: The Costs of Crime, Insecurity and Institutional Erosion. Chatham House (Royal Institution of International Affairs), London.

Lemieux, A., and Clarke, R. 2009. The international ban on ivory sales and is effects on elephant poaching in Africa. British Journal of Criminology, 49, 451-471.

Lin, D. 2014. What is poaching? Online at http://animalrights.about.com/od/ wildlife/g/What-Is-Poaching.htm. (downloaded 11 November 2015).

Lindsey, P., Nyirenda, V., Barnes, J., Becker, M., McRobb, R., . . . t'Sas-Rolfes, M. 2014. Underperformance of African protected area networks and the case for new conservation models: Insights from Zambia. PLOS ONE, 9(5), 1-14. Online at: ht tp://journals.plos.org/plosone/article/asset?id=10.1371\%2Fjournal.pone.009410. 9PDF. (downloaded on 23 July 2016).

Loibooki, M., Hofer, H., Campbell, K, and East, M. 2002.Bushmeat hunting by communities adjacent to the Serengeti National Park, Tanzania: The importance of livestock ownership and alternative sources of protein and income. EnvironmentalConservation, 29, 391-398.

Martin, A., and Caro, T. 2013. Illegal hunting in the Kativi-Rukwa ecosystem.African Journal of Ecology, 51, 172-175.

Messenger, S. 2013. Kenya significantly increases fines and jail time for poachers. Online at http://www.treehugger.com/environmental-policy/kenya-increases-fi nes-poaching.html. (downloaded 12 February 2014).

Milliken, T., Emslie, R., and Talukdar, B. 2009. African and Asian rhinocerosesStatus, conservation and trade. IUCN Species Survival Commission. https://cities. org/common/cop.15/doc/E15-45-01A.pdf. (downloaded 15 October 2015). 
Mole National Park. 2010. Mole National Park Business Plan, 2010-2020.

Muhumuza, M., and Balkwill, K. 2013. Factors affecting the success of conserving biodiversity in national parks: A review of case studies from Africa. International Journal of Biodiversity, 2013, Article ID 798101, 1-17.

Musgrave, R., Parker, S., \&Wolok, M. (1993). The status of poaching in the United States-Are we protecting our wildlife? Natural Resources Journal, 33, 9771014.

Musyoki, C., Andanje, S., Said, M., Chege, M.,Anyona, G., Lukaria, L., andKuloba, B.2012. Challenges and opportunities for conserving some threatened species in Kenya. The George Wright Forum, 29, 81-89.

Muth, R. and Bowe, J. 1998. Illegal harvest of renewable resources in North America: Towards a typology of the motivations for poaching. Society and Natural Resources, 11, 9-24.

Niraj, S. 2009.Sustainable development, poaching, and illegal wildife trade in India (Unpublished dissertation) University of Arizona.

Njiforti, H. 1996. Preferences and present demand for bushmeat in north Cameroon: some implications for wildlife conservation. Environmental Conservation, 23(2), 149-155. DOI= http://dx.doi.org/10.1017/S0376892900038534.

Ofori-Frimpong, B. 2004. Evolution of wildlife protection in Ghana. Unpublished paper delivered at a symposium organized by the Wildlife and Range Management Department at the College of Renewable Natural Resources, Sunyani, Ghana.

Poaching and terrorism: Hearing before the Subcommittee on Terrorism, Nonproliferation, and Trade of the Committee on Foreign Affairs,House of Representatives, $114^{\text {th }}$ Cong. 12015.

Population Reference Bureau. 2013. World population data sheet 2013. Online at http://www.prb.org/Publications/Datasheets/2013/2013-world-population-datasheet/data- sheet.aspx. (downloaded 23 July 2016).

Quarterman, M. 2013. Elephant killings surge as tusks fund terror. CNN. Online at http://edition.cnn.com/2013/06/19/opinion/quarterman-elephant-slaughter. (downloaded 12 January 2016).

Sadler, G., Lee, H., Lim, R., and Fullerton, J. 2010. Recruitment of hart-to-reach population subgroups via adaptations of the snowball sampling strategy. Nursing and Health Sciences, 12, 369-374.

Schmit, K. and Adu-Nsiah, M. 1993. The vegetation of Mole national Park. Forest Resource Management Project, GWD/IUCN Project 9786, Accra, Ghana.

Scriber, B. 2014. 100,000 elephants killed by poachers in just three years, landmark analysis finds. National Geographic, Online athttp://news.nationalgeographic. com/news/2014/08/140818-elephants-africa-poaching-cities-census.html. (downloaded 11 January 2016).

Shauer, J. 2015. The elephant problem: Science, bureaucracy and Kenya's national parks, 1955 to 1975. African Studies Review, 58, 177-198.

Sutherland, E. 1974.Criminology, 9th edn. Lippincott, Philadelphia, PA.

Sykes, G. and Matza, D. 1957. Techniques of neutralization: A theory of delinquency. American Sociological Review, 22, 664-670.

Thornycroft, P. and Laing, A. 2013. Poachers kill 300 Zimbabwe elephants with cyanide. Online at http://www.telegraph.co.uk/news/worldnews/africaandocean/ Zimbabwe/10390634/Poachers-kill-300-Zimbabwe-elephants-with-cyanide.Html. (downloaded 15 October 2015)._2_2000_van_Dijk_Stuart_Rhodin_Asian_Tur tle_Trade.pdf. (downloaded 5 October 2015). 
Vira, V., \& Ewing, T. 2014. Ivory's curse: The militarization \& professionalization of poaching in Africa. Born Free/C4ADS, Online at http://www.rhinoresourcec enter.com/pdf_files/139/1398 477046.pdf (downloaded 18 July 2016).

Vold, G., Bernard, T., and Snipes, J. 2002.Theoretical criminology, 5th edn. Oxford University, New York.

Walker, J. 2013. Rethinking ivory: Why trade in tusks won't go away. World Policy Journal, 30, 91-100.

Wilson-Wade, L. 2010. Wildlife crime: A global problem. Forensic Science, Medicine and Pathology, 6, 221-222.

Woodroffe, R., Thirgood, S., and Rabinowitz, A. 2005. The impact of human-wildlife conflict on natural systems. In Woodroffe R, ThirgoodS, Rabinowitz A (eds) People and wildlife: Conflict or coexistence? Cambridge University, New York, pp. 1-12.

Wu, S., Liu, N., Zhang, Y. and Ma, G. (2004). Assessment of threatened status of Chinese pangolin (Manis pentadactyla). Chinese Journal of Applied Environmental Biology, 10(4), 456-461. 